\title{
Kenttätutkimus akateemisten tutkijoiden informaatiovuorovaikutuksesta digitaalisissa ympäristöissä
}

\author{
Laura Korkeamäki \\ Tampereen yliopisto \\ Korkeamaki.Laura.K@student.uta.fi
}

Tässä abstraktissa käsittelen tulevan väitöstutkimukseni aihetta. Suunnitelmani on toteuttaa kenttätutkimus, jossa seurataan akateemisten tutkijoiden työskentelyä todellisissa työympäristöissä ja hahmotetaan, millä tavoin tutkijat ovat vuorovaikutuksessa informaation kanssa. Mielenkiinnon kohteena ovat todelliset työtehtävät, joissa hyödynnetään digitaalisia työkaluja ja tietoresursseja. Jatkan väitöstutkimuksessani samoja teemoja, joita käsittelin pro gradu -tutkielmassani (Korkeamäki, 2018). Näitä ovat tehtäväperusteisuus, informaatiovuorovaikutus ja digitaaliset ympäristöt. Seuraavaksi esittelen nämä teemat lyhyesti.

Tehtäväperusteisuus tarkoittaa esimerkiksi sitä, että toimintaa tarkastellaan osana tehtävän suorittamista. Lisäksi tehtävän tekijällä on mielessään jokin tavoite, jonka hän haluaa saavuttaa. (Byström \& Hansen, 2005.) Aiemmin tehtäväperusteista tutkimusta informaatiotutkimuksen saralla ovat tehneet esimerkiksi Byström (1999), Kumpulainen (2013) ja Saastamoinen (2017). Kuten heillä, myös omassa väitöstutkimuksessani huomio tulee olemaan nimenomaan todellisten tehtävien tutkimisessa. Tehtäviä voidaan tutkia monesta eri näkökulmasta. Väitöstutkimuksessani tulen todennäköisesti keskittymään tehtävien tavoitteiden ja tehtäväprosessien tutkimiseen.

Informaatiovuorovaikutuksesta ovat kirjoittaneet esimerkiksi Blandford ja Attfield (2010) sekä Fidel (2012). Sillä tarkoitetaan nimenomaisesti ihmisen ja Artikkeli on lisensoitu Creative Commons Nimeä-EiKaupallinen-JaaSamoin 4.o Kansainvälinen -lisenssillä 
informaation vuorovaikutusta (Fidel, 2012, s. 17). Pro gradu -tutkielmassani (Korkeamäki, 2018) sovelsin Järvelinin ym. (2015) laatimaa tehtäväperusteisen informaatiovuorovaikutuksen arviointikehystä. Siinä informaatiovuorovaikutusta tarkastellaan keskittymällä ihmisen kognitiivisiin toimintoihin ja käyttäytymiseen tehtävien tekemisen aikana. Informaatiovuorovaikutus on kiinnostava näkökulma tutkimukselle, koska sen avulla - kuten Järvelinin ym. (2015) arviointikehys osoittaa - voidaan tutkia kattavasti erilaisia tutkimustyön vaiheita.

Keskityn väitöstutkimuksessani digitaalisiin ympäristöihin, jotka ovat tärkeä osa akateemisten tutkijoiden työtä. Digitaalisilla ympäristöillä tarkoitetaan esimerkiksi digitaalisten laitteiden mahdollistamia "paikkoja” tai toimintaympäristöjä (Vuorikari, Punie, Carretero, \& Van den Brande, 2016, s. 10). Olen valinnut väitöstutkimukseeni käyttäjäkeskeisen näkökulman. Käyttäjäkeskeistä tutkimusta tarvitaan, jotta digitaaliset työkalut vastaisivat akateemisten tutkijoiden todellisia käyttötarpeita.

\section{Tutkimusmenetelmät}

Tarkoituksenani on rekrytoida tutkimukseen osallistujiksi tutkijoita eri yliopistoista Suomessa, ja muutamilta eri tieteenaloilta. Keskeinen tutkimusmenetelmä tulee olemaan varjostus, jota myös esimerkiksi Kumpulainen (2013) käytti omassa tutkimuksessaan. Varjostus on havainnointimenetelmä, jossa tutkija voi havainnoinnin aikana myös esittää kysymyksiä tutkittavalle ja keskustella tutkittavan kanssa. Menetelmän avulla voidaan saada todellisen elämän tilanteista sellaista tietoa, joita on vaikea saada muilla tutkimusmenetelmillä. Varjostuksen aikana kenttämuistiinpanoja voidaan kerätä esimerkiksi muistivihkoon. (McDonald, 2005.) Tulen todennäköisesti yhdistämään varjostukseen myös muita tiedonkeruumenetelmiä, kuten haastatteluja, lokin keräämistä tai videointia. Tutkimalla todellisia työtehtäviä voidaan saada parempi käsitys siitä, millä tavoin erilaisia digitaalisia työkaluja ja tietoresursseja käytetään, ja edelleen, miten niitä tulisi kehittää.

\section{Lähteet}

Blandford, A., \& Attfield, S. (2010). Interacting with Information. Synthesis Lectures on HumanCentered Informatics, 3(1), 1-99. https://doi.org/10.2200/S00227ED1V01Y200911HCI006

Byström, K. (1999). Task complexity, information types and information sources : examination of relationships (tohtorinväitöskirja). University of Tampere. http://tampub.uta.fi/handle/ 10024/67773 
Byström, K., \& Hansen, P. (2005). Conceptual framework for tasks in information studies. Journal of the American Society for Information Science and Technology, 56(10), 1050-1061. https: //doi.org/10.1002/asi.20197

Fidel, R. (2012). Human Information Interaction: An Ecological Approach to Information Behavior. Cambridge, Mass.: MIT Press.

Järvelin, K., Vakkari, P., Arvola, P., Baskaya, F., Järvelin, A., Kekäläinen, J., ... Sormunen, E. (2015). Task-Based Information Interaction Evaluation: The Viewpoint of Program Theory. ACM Trans. Inf. Syst., 33(1), 3:1-3:30. https://doi .org/10.1145/2699660

Korkeamäki, L. (2018). Historiantutkijoiden tehtäväperusteinen informaatiovuorovaikutus digitaalisissa ympäristöissä (Pro gradu -tutkielma). Tampereen yliopisto. http://urn.fi/URN: NBN: fi: uta- 201809062467

Kumpulainen, S. (2013). Task-based information access in molecular medicine: task performance, barriers, and searching within a heterogeneous information environment. Tampere: Tampereen yliopisto. http://urn.fi/URN: ISBN: 978-951-44-9287-7

McDonald, S. (2005). Studying actions in context: a qualitative shadowing method for organizational research. Qualitative Research, 5(4), 455-473. https://doi.org/10.1177/ 1468794105056923

Saastamoinen, M. (2017). Information searching in authentic work tasks: A field study on the effects of task type and complexity. Tampere: Tampereen yliopisto. http://urn. fi/URN: ISBN: 978-95203-0310-5

Vuorikari, R., Punie, Y., Carretero, S., \& Van den Brande, L. (2016). DigComp 2.0 : the digital competence framework for citizens. Luxembourg: Publication office of the European Union. https://doi.org/10.2791/11517 